\title{
PEMISAHAN KEKUASAAN HUBUNGAN PRESIDEN DAN DEWAN PERWAKILAN DAERAH DALAM FUNGSI LEGISLASI"
}

\author{
Zulfan \\ Fakultas Hukum Universitas Samudera \\ Jl. Kampus Meurandeh Kota Langsa. 24354 \\ E-mail: fan_djalil@yahoo.co.id
}

\begin{abstract}
The issue of separation of powers related to the relationship between the president and the Council of Regional of Representative, has had ups and downs in Indonesia. This research would like to answer what is the basis and procedure of the separation of powers in the function of legislation of the era of the Kabinet Kerja? This research moved from the critical reconstruction of the theory concerning the division of power functions by focusing on the era of the Kabinet Kerja. This Cabinet is a Transition of the reformist regime. The complete separation of powers in the Jokowi government of both the executive, legislative and judiciary institutions is not self-sufficient and mutually controlled through the political deal of the Koalisi Merah Putih and Indonesia Hebat ends in the hope of sharing power.
\end{abstract}

Keywords: separation of power, legislation function.

\begin{abstract}
Abstrak
Masalah pemisahan kekuasaan terkait hubungan presiden dan Dewan Perwakilan Daerah, mengalami pasang surut di Indonesia. Penelitian ini ingin menjawab apakah dasar dan prosedur pemisahan kekuasaan dalam fungsi legislasi era Kabinet Kerja? Penelitian ini beranjak dari rekonstruksi kritis teori berkaitan pembagian fungsi kekuasaan dengan berfokus pada era Kabinet Kerja. Kabinet ini merupakan Transisi rezim reformasi. Pemisahan kekuasaan dalam pemerintahan Jokowi secara utuh baik lembaga eksekutif, legislatif maupun yudikatif tidak mandiri serta saling menguasai melalui deal politik Koalisi Merah Putih dan Indonesia Hebat berakhir pada pengharapan membagi kekuasaan.
\end{abstract}

Kata Kunci: Pemisahan kekuasaan, fungsi legislasi.

\section{A. Pendahuluan}

\section{Latar Belakang}

Faham ajaran para bapak pendiri (the founding fathers) Republik Indonesia yang perlu dihayati dan telah disepakati bersama 4 (empat) konsensus dasar kebangsaan yaitu: Pancasila, Undang-Undang Dasar (UUD) 1945, Negara Kesatuan Republik Indonesia (NKRI) dan Bhinneka Tunggal Ika. Meskipun Mahkamah Konstitusi melalui amar putusan nomor $100 /$ PUU-XI/2013 telah membatalkan kalimat frasa empat pilar berbangsa dan bernegara(Konstitusi, 2014). Ketua Hakim Konstitusi Arief Hidayat memiliki alasan berbeda (concurring opinion) terhadap putusan tersebut
(Konstitusi, 2014). Mengkaji kembali dokumen naskah otentik peristiwa hukum konstitusi Undang-Undang Dasar 1945 masa lalu tentunya dianggap penting dan bermakna dalam sejarah ketatanegaraan Indonesia. Pasca reformasi naskah teks perubahan keempat UUD NRI 1945 dapatlah dipahami sebagai cara baca yang sangat intoleran terhadap fakta. Pemahaman perubahan sering mengejutkan bahkan menjadi gelombang protes.

Penulis memahami naskah teks UUD NRI 1945 pasca perubahan, kendatipun demikian karakteristik teks tersebut dibangun atas kematangan bersama oleh para bapak pendiri (the founding fathers) Republik 
Indonesia melalui konsiderasi filosofis, sosiologis, yuridis maupun politis. Konstitusi Indonesia telah melahirkan hukum dasar dan prosedur, pengaturan maupun praktik terhadap pembagian kekuasaan kewenangan DPR-RI membentuk undang-undang. Sedangkan pelaksanaan oleh Presiden sebagai kepala negara (chief of state) dan dibantu para menteri.

Kajian Harun Alrasid menyebutkan bahwa kedudukan Presiden dalam UUD 1945 baik yuridis maupun politis adalah penting, Presiden memiliki kekuasaan tanggungjawab yang sangat besar (concentration of powers and responsibilities upon the president). Jabatan Presiden sangat penting mendapat refleksi dalam pengaturan mengenai jabatan Presiden. UUD 1945 menjadi UUD yang hidup (a living constitution). (Alrasid, 1993) Hal ini terkait bahwa Indonesia sebagai negara hukum (rechtsstaat atau the rule of law) adalah konsep negara yang diidealkan the founding father bangsa menjadikan hukum sebagi panglima dalam dinamika kehidupan kenegaraan tidak berdasarkan atas kekuasaan (machtsstaat). (Alrasid, $1993)$. Kedaulatan rakyat menganggap kekuasaan tertinggi tercermin dalam hukum, jika demokrasi kekuasaan tertinggi berada di tangan rakyat, maka nomokrasi kekuasaan tertinggi tercermin dalam norma hukum yang berlaku, seperti tergambar dalam istilah the rule of law (Alrasid, 1993). Indonesia suatu negara berdasarkan atas hukum (Rechtsstaat) dengan pengertian bahwa pola yang diambil tidak menyimpang dari negara berdasarkan atas hukum umumnya (genus begrip), sesuai keadaan di Indonesia(Asshidiqie, 2007).

Berdasarkan gambaran tersebut, penting ditegaskan konstitusi sebagai sebuah catatan tertulis, dapat ditemukan dalam bentuk dokumen yang bisa diubah atau diamandemen menurut kebutuhan perkembangan zaman. Tujuan suatu konstitusi adalah membatasi tindakan sewenang-wenang pemerintah, menjamin hak-hak rakyat yang diperintah dan menetapkan pelaksanaan kekuasaan berdaulat (Asshidiqie, 2007). Artinya, negara dalam pengertian luas harus memiliki tiga kekuasaan pemerintahan mencakup, legislatif, eksekutif dan yudikatif. Sedangkan pemerintahan dalam pengertian sempit hanya eksekutif. Menurut Hans Kelsen mewakili tradisi pemikiran tentang hukum dan negara menjelaskan bahwa norma dasar konstitusi menempati urutan tertinggi dalam hukum nasional. Konstitusi di sini dipahami bukan dalam arti formal, melainkan dalam arti material (Kelsen, 2006). Oleh salah satu murid Hans Kelsen, yakni Hans Nawiasky menyebutkan Konstitusi sebagai staatsfundamentalnorm terlebih dahulu ada dari konstitusi merupakan norma dasar pembentukan Undang-Undang Dasar (staatsverfassung) pada sebuah konstitusi. Posisi hukum suatu Staatsfundamentalnorm adalah sebagai syarat berlakunya suatu konstitusi(Kelsen, 2006).

Penelitian tentang sistem demokrasi dan pemerintahan presidensial di Indonesia sudah pernah dikaji dalam beberapa disertasi seperti, Arief Hidayat (Hidayat, 2005), Saldi Isra (Isra, 2006). Dua kajian ini belum secara khusus mengkaji pemisahan kekuasaan (separation of Power) atas dasar dan prosedur, pengaturan. Disamping itu, keberadaan lembaga kepresidenan, kedudukan, agenda kebijakan maupun komunikasi dan retorika presiden serta praktik hubungan presiden dengan DPD-RI dalam fungsi legislasi. Selain itu, banyak literatur kajian mengenai fungsi legislasi parlemen dari perspektif umum. Akan tetapi, penelitian ini diharapkan dapat membahas lebih rinci, apakah dasar dan prosedur pemisahan kekuasaan hubungan Presiden dengan Dewan Perwakilan Daerah Republik Indonesia dalam fungsi legislasi yang diatur UUD NRI Tahun 1945 era Kabinet Kerja?

\section{Metode Penelitian}

Metode penelitian merujuk pada teoriteori hukum dan negara dengan tujuan kritis dalam mengembangkan argumen kajian berorientasi pada dasar dan prosedur, pengaturan. Penelitian ini menawarkan rekonstruksi analisis kajian kritis terhadap konflik teori hukum konstitusi Indonesia. Berdasarkan permasalahan yang diangkat dalam penelitian disertasi ini adalah, penelitian doktrinal (normatif), dengan menggunakan metode pendekatan penelitian hukum normatif melalui pendekatan 
perundang-undangan (statute approach) (Ibrahim, 2005), pendekatan sejarah hukum (historical approach) (Soerjono Soekanto, 2007), pendekatan konseptual (conceptual approach) (Ibrahim, 2005), pendekatan perbandingan hukum (comparative law approach) (Hartono, 1989) serta pendekatan perbandingan hukum konstitusi (Comperative constitutional law approach) (Hirschl, 2014).

Berdasarkan sumbernya, jenis data penelitian meliputi data primer dan sekunder. Untuk memperoleh data primer, peneliti menggunakan telaah dan wawancara. Data sekunder berasal dari bahan hukum primer, yakni: Naskah UUD 1945 asli; Risalah Sidang BPUPKI; Naskah UUD NRI Tahun 1945, jilid 1-10 terbitan MKRI; UndangUndang Nomor 22 Tahun 2003 tentang Susunan dan Kedudukan Majelis Permusyawaratan Rakyat, Dewan Perwakilan Rakyat, Dewan Perwakilan Daerah, dan Dewan Perwakilan Rakyat Daerah; Undang-Undang Nomor 24 Tahun 2003 tentang Mahkamah Konstitusi sebagaimana telah diubah dengan UndangUndang Nomor 8 Tahun 2011 tentang Perubahan Atas Undang-Undang Nomor 24 Tahun 2003 tentang Mahkamah Konstitusi; Undang-Undang Nomor 27 Tahun 2009 tentang Majelis Permusyawaratan Rakyat, Dewan Perwakilan Rakyat, Dewan Perwakilan Daerah dan Dewan Perwakilan Rakyat Daerah, diganti Undang-Undang Nomor 17 Tahun 2014 tentang Majelis Permusyawaratan Rakyat, Dewan Perwakilan Rakyat, Dewan Perwakilan Daerah, dan Dewan Perwakilan Rakyat Daerah. Undang-Undang Nomor 48 Tahun 2009 tentang Kekuasaan Kehakiman; Undang-Undang Nomor 12 Tahun 2011 tentang Pembentukan Peraturan Perundang-Undangan .

Penelitian menggunakan pemeriksaan melalui sumber lainnya (triangulasi) berbagai sumber data untuk meningkatkan generalisasi temuan. Proses analisis dilakukan dengan pengelompokan data yang terkumpul dan dicermati untuk menemukan prinsip-prinsip berdasarkan kerangka teori yang akan menjadi pedoman pembahasan.

\section{B. Hasil dan Pembahasan}

Pemilu presiden secara langsung pada tanggal 9 Juli 2014, Joko Widodo terpilih menjadi presiden masa periode 2014-2019. Pada tanggal 14 Oktober 2014, Indonesia memasuki sejarah baru dengan indikasi bahwa merangkul demokrasi dan berpaling dari rezim otoriter. Hal ini, Joko Widodo menawarkan revitalisasi periode pasca reformasi(Wigins, 2015).

Pembagian kekuasaan dalam sistem multi partai tidak terlepas dari bagian norma perpolitikan Indonesia. Dengan demikian, belajar dari pemerintahan Orde Baru partai politik diizinkan dan eksis dalam setiap pemilu hanya 3 partai. Disamping itu, Indonesia terus mengalami masalah terkait dengan multi partai yang selalu paradoks untuk membatasi negara dari sistem pemerintahan otoriter. Pasca reformasi sistem pemilu diadakan perubahan sesuai sistem politik negara, sehingga melahirkan kembali sistem multi partai. Oleh karena itu, sistem pemilu sangat penting untuk menjembatani hak individu dari hasil politik mencakup sifat dari partai politik. Dengan demikian, ada dua bentuk pemilu yaitu, (1) perwakilan proporsional (PR), mengacu pada aturan yang digunakan untuk mendistribusikan beberapa kursi dari beberapa partai politik sesuai dengan perolehan suara partai politik; (2) pluralitas atau sistem mayoritas di mana kursi diberikan kepada calon atau partai politik (Vermonte, 2006).

Dasar dan prosedur pemisahan kekuasaan sistem pemerintahan presidensial pasca pemilu tahun 2014, telah menetapkan Jokowi-JK melalui Keputusan Komisi Pemilihan Umum Pusat sebagai Presiden dan Wakil Presiden terpilih (Keputusan KPU Nomor 536/KPTS/KPU/Tahun 2014, Tentang Penetapan Pasangan Calon Presiden dan Wakil Presiden Terpilih Dalam Pemilihan Umum Presiden dan Wakil Presiden Tahun 2014). Hal ini, berdasarkan UUD NRI Tahun 1945 Pasal 9 Ayat (1) dan (2).

Berdasarkan UUD NRI Tahun 1945 secara tegas mewajibkan Presiden dan Wakil Presiden bersumpah dihadapan MPR-RI sebelum memangku jabatan dengan bertepatan berakhirnya masa jabatan. Prosedur acara pelantikan diatur melalui 
Pasal 161 Ayat (1) dan (2) Undang-Undang Nomor 42 tahun 2008 menyatakan: bahwa pasangan Calon terpilih dilantik menjadi Presiden dan Wakil Presiden oleh Majelis Permusyawaratan Rakyat. Dalam hal calon Wakil Presiden terpilih berhalangan tetap sebelum pelantikan, calon Presiden terpilih dilantik menjadi Presiden.

Dasar tujuan bernegara adalah, sebagaimana terkandung dalam pembukaan UUD NRI Tahun 1945 melindungi segenap bangsa Indonesia dan seluruh tumpah darah Indonesia, memajukan kesejahteraan umum, mencerdaskan kehidupan bangsa dan ikut melaksanakan ketertiban dunia berdasarkan kemerdekaan, perdamaian abadi dan keadilan sosial. Artinya, bersifat mengikat dan m e maks a d e m i mew u j d kan penyelenggaraan kehidupan kenegaraan demokratis. Hal ini, pasca reformasi terlihat bahwa, dasar dan prosedur pemisahan kekuasaan dalam sistem pemerintahan presidensial tidak sesuai dengan demokrasi pancasila. Akan tetapi, model demokrasi pemerintahan Jokowi-JK berdasarkan serba suka dalam pengertian mengambil yang suka dan menjauhkan persoalan yang dapat mengganggu kinerja pemerintahan, sehingga mengesampingkan prinsip demokrasi. Kendatipun demikian, dasar dan prosedur pemisahan kekuasaan harus berdasarkan konstitusi demokratis, hukum, perlindungan Hak Asasi Manusia, jaminan kebebasan setiap warga negara, pengakuan terhadap hak minoritas, partai politik lebih dari satu, pemilihan umum secara bebas, mufakat dan musyawarah, transparan, pengawasan terhadap administrasi negara, pers independen, penyelesaian konflik secara damai dan peradilan bebas tidak memihak. Pemisahan kekuasaan sistem pemerintahan Jokowi-JK secara utuh baik lembaga eksekutif, legislatif maupun yudikatif tidak mandiri. Artinya, ketiga lembaga tersebut saling mengusai melalui deal politik antara Koalisi Merah putih dan Indonesia hebat yang berakhir pada pengharapan membagibagikan kekuasaan.

Terkait dengan pengaturan pemisahan kekuasaan, sejarah konstitusi Indonesia telah memberi ruang tentang pengaturan pemisahan kekuasaan presiden dalam tiga versi UUD 1945: (1) UUD asli; (2) pengaturan perubahan Pertama dan Kedua UUD NRI Tahun 1945 kedudukan presiden sangat lemah; dan (3) pasca perubahan ketiga dan keempat UUD NRI Tahun 1945 secara signifikan telah memperkuat kedudukan presiden.

Pengaturan pemisahan kekuasaan sistem pemerintahan presidensial membutuhkan pemimpin kuat. Hal ini, Indonesia sejak tahun 1999 mendukung sistem multipartai yang cukup berat. Konsekuensinya, terletak pada jawaban tercipta suatu pola komunikasi yang baik antara eksekutif dan legislatif di era pemerintahan kekinian sehingga memasukkan kritikan membangun serta membutuhkan waktu, mengingat hubungan presiden dengan legislatif masih kerap diwarnai perbedaan pendapat. Meskipun demikian, kini muncul masalah pelik terkait soal toleransi dan penistaan agama berujung aksi demonstrasi besar-besaran bela Islam I dilakukan 4 November 2016 maupun bela Islam III 2 Desember 2106. Hal ini, intoleransi masih mewarnai kehidupan sehari-hari dalam masyarakat Indonesia, terjadi di tempat dan waktu yang berbeda. Pemerintah dalam 2 tahun pertama harus merespon isu-isu politik dan ekonomi, faktanya pemerintahan Jokowi memperlihatkan kegamangan menangani letupan persoalan berdimensi intoleransi atau konflik antar kelompok identitas. Namun, bukan berarti pemerintahan sebelumnya telah lebih baik merespons persoalan sejenis.

Indonesia era kekinian perlu menempatkan dan memperkuat lembaga kepresidenan dalam pemisahan kekuasaan sistem pemerintahan presidensial yang demokrasi lebih stabil dibandingkan parlemenenter. Akan tetapi, ketidakstabilan disebabkan lemahnya kinerja yang dihasilkan oleh presidensial itu sendiri. Demokrasi lembaga kepresidenan mati suri bukan karena memaksa lembaga mencari solusi di luar konstitusional konflik sesama mereka. Konflik tentunya dipahami mengapa demokrasi jenis apa pun harus lepas dari sistem otoriter. Jika hal ini terjadi, maka Indonesia berada dalam posisi menggeser penekanan pemikiran reformasi politik 
modern dalam negara demokrasi. Banyak literatur tentang bentuk pemerintahan demokrasi terpusat pada hubungan antara presiden dan legislatif, dugaan keterlibatan hubungan ini diatur sesuai konstitusi. Adapun negara yang menganut sistem pemerintahan presidensial yaitu, Indonesia, Amerika Serikat, Swiss, Cina, Filipina, Brazil dan Argentina. Sedangkan Amerika Serikat sebagai negara pelopor sistem pemerintahan presidensial telah mempraktikkan secara konsisten prinsip-prinsip pemerintahan demokrasi.

Presiden Joko Widodo membentuk lembaga kepresidenan lebih kuat dan efektif untuk mewakili tugas-tugas presiden, sehingga lembaga ini menjadi saluran aspirasi masyarakat sipil bagi pemerintah untuk dapat membantu kinerja Presiden. Mempertegas substansi kebijakan dengan melakukan pendekatan komprehensif dan sistematik. Seperti, menyelesaikan Rancangan UndangUndang substantif diuji terlebih dahulu, sebelum diajukan ke DPR-RI sebagai salah satu indikator penting keberhasilan pemerintahan Jokowi harus mampu mengelola partisipasi publik dalam tata kelola sebagai sebuah paradigma baru dalam kehidupan kenegaraan modern. Disamping itu, lembaga kepresidenan diharapkan publik dapat memperkuat posisi Jokowi dalam menghadapi dominasi oposisi parlemen. Presiden Jokowi telah membentuk Unit Staf Kepresidenan dipimpin kepala Staf Kepresidenan. Pembentukan unit menjadi lembaga untuk mereduksi kewenangan wapres dan para menteri koordinator, termasuk menteri sekretaris negara dan sekretaris kabinet di lingkungan lembaga kepresidenan. Lembaga kepresidenan merupakan pintu terakhir kebijakan negara, bahkan sebagai jantung negara sehingga kedudukannya sangat vital. Artinya, hal yang sangat mendesak adalah segera membuat Undang-Undang tentang lembaga kepresidenen.

Terkait dengan kedudukan DPD, berdasarkan sejarah memperlihatkan hal yang menarik. Mahkamah Konstitusi Republik Indonesia telah memainkan peran penting dalam transformasi negara demokrasi paling stabil di Asia Tenggara. Pengadilan telah maju dengan mekanisme resolusi konflik kelembagaan dan memperluas demokrasi konsolidasi. Membangun model Mahkamah Konstitusi telah mampu mempertahankan otonom kekuasaan sebagai kunci keberhasilan, hakim dalam aktivisme peradilan sangat populer memberikan keputusan. Dengan demikian, Mahkamah Konstitusi mendapat dukungan masyarakat Indonesia dan kebal terhadap upaya intervensi eksternal (Mietzner, 2010). Lembaran baru sejarah kehidupan kenegaraan telah mencatat bahwa pasca Mahkamah Konstitusi memberikan putusan Nomor:79/PUU-XII/2014, menegaskan kewenangan legislasi DPD-RI dan telah meluruskan kembali makna Pasal 22D ayat (1) dan (2) UUD NRI 1945.

Sistem kehidupan kenegaraan Indonesia secara konstitusional DPD-RI sudah diberikan tempat yang seharusnya, hak serta kewenangan untuk mengajukan dan ikut membahas Rancangan Undang-Undang dari awal sampai akhir, baik dalam pembahasan maupun penentuan DIM. Artinya, sejauh menyangkut kewenangan dalam proses Rancangan Undang-Undang sebagaimana diatur pada Pasal 22 D Ayat (1) dan (2) UUD NRI 1945 yang tidak melibatkan DPD-RI cacathukum.

Konstitusi telah meluruskan kembali makna perubahan Pasal 22 D Ayat (1) dan (2) UUD NRI 1945 sesuai tujuan reformasi. Mahkamah Konstitusi lebih jauh memberikan hak kepada DPR-RI, DPD-RI dan Presiden bersama-sama dalam prolegnas. Pasca putusan Mahkamah Konstitusi DPD-RI tidak ikut serta dalam proses persetujuan RUU menjadi Undang-Undang. Ketika DPD-RI ikut dalam pembahasan secara detil dan komprehensif semua makna substantif dalam Rancangan Undang-Undang yang sudah dibahas akan sangat kecil untuk tidak memasukkan semua usulan-usulan tersebut, secara praktis itulah hasil kesepakatan pembahasan.

Pasca putusan Mahkamah Konstitusi terhadap kewenangan DPD-RI merupakan putusan bulat konstitusional legislasi walaupun tidak ada the santing opinion. Mahkamah sebagai penjaga konstitusi lahir sejak era reformasi, ke depan diharapkan 
sebagai arsitektur kehidupan kenegaraan khususnya dalam proses legislasi akan mengalami adjustmant sesuai putusannya. Proses legislasi di DPR-RI tidak lagi menjadi deliberasi monopoli. Akan tetapi, proses deliberasi legislasi itu menjadi hak konstitusional DPR-RI, DPD-RI dan Presiden. Selanjutnya, DPD-RI sudah membuktikan bahwa tidak meminta tambahan kewenangan, akan tetapi memohon tafsir Undang-Undang MD3 dan UU P3 atas UUD NRI 1945. Dengan demikian, pandangan DPD-RI dan pakar ahli maupun para hakim Mahkamah Konstitusi seluruhnya sama menyangkut 3 (tiga) hal yaitu: (1) Rancangan Undang-Undang inisiatif; (2) ikut membahas dan (3) prolegnas. Putusan ini merupakan hasil perjuangan negosiasi selama 2 perieodesasi DPD-RI. Hal ini, bunyi putusan bahwa keikutsertaan seluruh DPD-RI dalam pembahasan setara dengan DPR-RI demikian juga Presiden. DPR-RI, DPD-RI maupun Presiden memiliki hak yang sama dalam usul pengajuan Rancangan UndangUndang. Dengan demikian, jangan ada lagi istilah DPD-RI itu lemah. Kendatipun, DPDRI sudah menemukan jati dirinya sebagaimana tertuang dalam Pasal 22D ayat (1) dan (2) UUD NRI 1945, sehingga tidak ada lagi yang menguranginya. Dengan demikian, pernyataan DPD-RI terbukti bahwa Undang-Undang yang dibuat sebelum putusan Mahkamah Konstitusi merupakan inkonstitusional karena tidak mengikutsertakan DPD-RI. Dimana produk Undang-Undang berkaitan dengan otonomi daerah yang dibuat oleh DPR-RI tidak melibatkan DPD-RI, sehingga merupakan produk inkonstitusional. Pernyataan DPD-RI pasca putusan bahwa, Dewan Perwakilan Rakyat Republik Indonesia jangan melecehkan Mahkamah Konstitusi. Hal ini, sebagaimana sudah terbukti dalam UndangUndang Nomor 8 Tahun 2012 tentang Pemilu, keputusan Mahkamah Konstitusi tidak diindahkan oleh DPR-RI tentang domisili bagi calon anggota DPD-RI. Sehingga sudah diajukan permohonan judicial review dan dikabulkan bahwa, domisili harus dari daerah bersangkutan sehingga tidak diindahkan oleh DPR-RI. Putusan Mahkamah Konstitusi tidak berlaku surut, dan berlaku sejak putusan diucapkan. Dengan demikian, bila DPR-RI tidak mengindahkan putusan Mahkamah Konstitusi tentang MD3 dan P3, maka rakyat tidak mungkin membiarkan sikap yang dipertontonkan oleh DPR-RI .

Presiden Jokowi harus memperbaiki hubungan atau membangun kemitraan dengan DPR/DPD-RI yang akhir-akhir ini yang dianggap kurang harmonis dan dapat merugikan rakyat, sehingga berujung keluarnya Surat Edaran Sekretaris Kabinet Nomor SE-12/Seskab/XI/2014, meminta menteri dan pejabat setingkatnya menunda pertemuan dengan DPR-RI. Alasannya, memberi kesempatan kepada DPR-RI untuk melakukan konsolidasi kelembagaan secara internal. Hal ini, sebaiknya tidak perlu terjadi karena pemerintah butuh anggaran dalam melaksanakan pembangunan, sedangkan anggaran butuh persetujuan DPR-RI. Artinya, Presiden diberi amanah oleh rakyat untuk melaksanakan pembangunan. Akan tetapi, program pembangunan nasional tercapai bila kedua lembaga tersebut berjalan bersamasama, dan melaksanakan tugas sesuai fungsi legislasi maupun ketentuan perundangundangan. DPR/DPD-RI juga sedang membahas proses perubahan menyangkut beberapa pasal dalam Undang-Undang Nomor 17 Tahun 2014. Pemisahan kekuasaan dalam sistem pemerintahan presidensial kekinian dimana hubungan DPR/DPD-RI terlihat menunjukkan respon positif atas kebijakan yang dikeluarkan Presiden Jokowi, sebagai bentuk dukungan terhadap pemerintahannya. Disamping itu, hubungan komunikasi Presiden Jokowi dengan partai politik Koalisi Merah Putih merupakan pihak oposisi dari pemerintahan semakin membaik. Hal ini, menjadi bukti nyata adanya perbaikan hubungan presiden dengan DPR/DPD-RI dalam pelaksanaan fungsi legislasi masa dua tahun terakhir pemerintahan berjalan sesuai rencana. Meskipun, terjadi kerenggangan hubungan antara partai PDIP (Koalisi Indonesia Hebat) dan Presiden sebagai partai pendukung. Sebaliknya, justru Koalisi Merah Putih mendukung secara penuh terhadap beberapa kebijakan Presiden, meskipun tidak menemui hambatan dari legislatif saat proses pembahasan berlangsung. Seperti, pergantian calon Kapolri maupun pencabutan subsidi 
BBM dilaksanakan tanpa hambatan dari partai di lembaga legislatif.

Khususnya, kelembagaan yang berkaitan dengan pemilu, checks and balances dari presidensialisme atau hubungan antara presiden dan Kabinet selalu menghadapi perbedaan pendapat dengan legislatif yang tidak sesuai kehendak presiden dalam penentuan undang-undang. Seperti, faktor-faktor metode pemilihan presiden dan proses maupun waktu pemilihan dua lembaga tersebut merupakan faktor penting dalam mempengaruhi jumlah pesaing. Proses perwakilan pemilihan berinteraksi pada pembentukan eksekutif untuk membentuk fungsi rezim demokratis (Matthew Soberg Shugart, 2012).

Prinsip legislasi adalah periode penilaian kembali, setidaknya kesetiaan kepada cita-cita dasar politik individualisme, pemerintahan sendiri, demokrasi dan ditantang oleh faktor baru menekankan kekuatan dan kelemahan dalam menentukan nasib bangsa. Hal ini, sangat penting untuk berhati-hati dalam menarik kesimpulan sebelum waktunya dari kondisi normal dan mempertahankan beberapa kepercayaan prinsip-prinsip yang belum dibuktikan. Di tengah kebingungan nilai-nilai politik semua telah terkesan pentingnya prestasi dan tergoda untuk menuntut standar yang tinggi dalam pemerintahan sebagai ideal politik tak terbantahkan(Freund, 2013).

Karakter politik dan hukum hubungan lembaga presiden dan DPR/DPD-RI merupakan salah satu perangkat utama dari sistem politik hukum modern adalah sendi pengambilan keputusan otoritas legislatif dan eksekutif. Secara resmi sebagai pengaturan konstitusi negara tertentu dalam menentukan hubungan saling mengawasi dan membatasi antar berbagai cabang kekuasaan negara yang dikenal sebagai checks and balances, hadir di sebagian besar negara demokrasi pada struktur politik dan hukum. Di negara-negara transisi, pengawasan parlemen dari kekuasaan eksekutif adalah relatif baru dengan banyak tantangan di masa depan. Hal ini, setiap negara memastikan bentuk pemerintahan yang sah dan harus ada pengawasan parlemen sebagai kunci demokrasi, karena legislatif secara konstitusional bersifat substansial dapat mempengaruhi tindakan pemerintah. Sistem politik hukum demokratis menciptakan model kualitas pengawasan parlemen terhadap kekuasaan eksekutif.

Setiap negara hubungan antara otoritas eksekutif dan legislatif seringkali menjadi penyebab polemik dari politik dan hukum. Alasannya, terkait pada dasar fakta bahwa mekanisme kualitas pengawasan parlemen terhadap otoritas eksekutif tergantung tingkat sistem politik dan hukum yang demokratis. Secara sistematis mempengaruhi banyak hubungan sosial dan proses dalam bidang ekonomi, pendidikan dan lain-lain. Mekanisme pengawasan parlemen memiliki perbedaan dari sebagian besar bentuk prinsip dan tujuan yang sama, pengawasan legislatif sebagai badan perwakilan atas organ-organ kekuasaan eksekutif selama memerintah. Dengan demikian, pertimbangan pengawasan parlemen atas eksekutif dan otoritas administratif, masing-masing negara memiliki kekhususan tersendiri. Ketika sehubungan pelaksanaan kebijakan resmi hubungan antara otoritas eksekutif dan legislatif harus mempertimbangkan adanya perbedaan dalam cara pemisahan kekuasaan politik dan pengaruh masing-masing cabang kekuasaan. Seperti, kasus dua lembaga negara Presiden dan DPR/DPD-RI cenderung berlawanan untuk membatasi dominasi maupun pengawasan parlemen, sebagai badan perwakilan dalam arti tertentu memiliki kekuatan mengawasi kekuasaan eksekutif dengan mempertimbangkan konsep pemisahan kekuasaan ke legislatif, eksekutif, dan yudikatif. Tugas utama dan misi parlemen sebagai badan yang dibentuk atas dasar pilihan rakyat adalah untuk mengawasi. Parlemen sebagai badan perwakilan merupakan kehendak partai politik yang diwakili, mengadopsi atau menolak hukum yang diusulkan sesuai dengan prosedur demokratis, sebagai dasar hukum bagi tindakan administrasi pemerintahan. Penerapan hukum, justru parlemen memiliki salah satu fungsi utamanya mengawasi publik administrasi dengan eksekutif.

Peran parlemen dalam membatasi 
kekuasaan eksekutif selain keterbatasan hukum, kinerja dan fungsi legislasi melalui pengawasan. Subyek pengawasan hukum kekuasaan eksekutif hanya tindakan peraturan secara umum bukan individu. Inti pengawasan parlemen atas eksekutif tercermin dalam deal politik. Oleh karena itu, tugas pemeriksaan yang dilakukan parlemen bagaimana kinerja eksekutif untuk melindungi kepentingan publik dalam menjalankan kebijakan. Mekanisme politik pengawasan parlemen atas kekuasaan eksekutif dicapai melalui menteri, dimana hubungan antara presiden dan DPR/DPD-RI dan menteri adalah kepercayaan politik, ketika keseimbangan ini terganggu karena Presiden tidak bertindak atas perintah DPR/DPD-RI atau menyangkut kebijakannya tidak melakukan dengan cara keinginan legislatif. Hal ini, menyebabkan sanksi parlemen terhadap pemberhentian menteri. DPR/DPD-RI saat melakukan pengawasan dengan menggunakan sejumlah instrumen yaitu, interpelasi, survei, investigasi memeriksa keluhan warga tentang pekerjaan administrasi, pertimbangan laporan kinerja pemerintah, komite parlemen, aktivitas kontrol individu. Pengawasan DPR/DPD-RI sangat ditentukan oleh sistem pemerintahan. Pengaturan kekuasaan dalam sistem presidensial menggunakan prinsip pemisahan kekuasaan yang konsisten. Secara keseluruhan, sarana pengawasan parlemen atas pemerintah dibagi dalam dua bagian yaitu, (1) sarana D PR/DPD-R I menginformasikan kinerja pemerintah; (2) tanggung jawab politik Presiden di parlemen.

\section{c. Simpulan}

Naskah teks UUD NRI 1945, kendatipun karakteristik teks tersebut dibangun atas kematangan bersama para bapak pendiri bangsa melalui konsiderasi filosofis, sosiologis, yuridis maupun politis, namun tidak terlepas dari perkembangan ketatanegaraan. Perkembangan yang baik ditentukan oleh lembaga kepresidenan, kedudukan dan agenda kebijakan presiden, komunikasi dan keunggulan retorika presiden serta praktik hubungan presiden dengan MPR/DPR-RI khususnya DPD-RI dalam fungsi legislasi pada masing-masing periodesasi dulu dan kekinian.

Pada era Kabianet Kerja, dimana Jokowi merupakan transisi rezim reformasi bergaya otoriter terhadap pelembagaan demokrasi politik Indonesia. Hal ini, terlihat pemisahan kekuasaan dalam pemerintahan Jokowi secara utuh baik lembaga eksekutif, legislatif maupun yudikatif tidak mandiri serta saling mengusai melalui deal politik Koalisi Merah Putih dan Indonesia Hebat berakhir pada pengharapan membagi kekuasaan.

Terkait karakter khas sejarah sistem pemerintahan presidensial maupun parlementer Indonesia, pengaturan pembagian dan pemisahan kekuasaan dipengaruhi materi muatan konstitusi itu sendiri. Sejak 2 tahun pertama pemerintahan kabinet kerja harus merespon isu-isu politik, ekonomi maupun penegakan hukum semakin terpuruk, faktanya Jokowi memperlihatkan kegamangan menangani letupan persoalan berdimensi intoleransi atau konflik antar kelompok identitas. Namun, pemerintahan sebelumnya telah lebih baik merespons persoalan sejenis.

\section{DAFTAR PUSTAKA}

Alrasid, H. (1993). Masalah Pengisian Jabatan Presiden Di Indonesia; Sejak Sidang Dokuritzu Zyunbi Choosakai 1945 Sampai Sidang Majelis Permusyawaratan Rakyat 1993, Suatu Tinjauan Formal Yuridis. PDIH UI: Jakarta.

Asshidiqie, J. (2007). Pokok-Pokok Hukum Tata Negara Indonesia Pasca Reformasi. Jakarta: Bhuana Ilmu Populer.

Freund, E. (2013). Principles of Legislation. American Political Science Review.

Hartono, S. (1989). Kapita Selekta

Perbandingan Hukum, cet.4. Bandung: Citra Aditya Bakti.

Hidayat, A. (2005). Kebebasan Berserikat Di Indonesia, Suatu Analisis Pengaruh Perubahan Sistem Politik Terhadap Penafsiran Hukum. Semarang: PDIH Undip.

Hirschl, R. (2014). Comparative Matters the Renaissance of Comparative 
Constitutional Law, . Oxford: Oxford University Press.

Ibrahim, J. (2005). Teori Metode dan Penelitian Hukum Normatif, cet.1. Malang: Bayumedia Publishing.

Isra, S. (2006). Menguatnya Model Legislasi Parlementer Dalam Sistem Presidensial Indonesia. Yogyakarta: PDIH UGM.

Kelsen, H. (2006). General Theory of Law and State, terjemahan Raisul Muttaqien, Teori Umum tentang Hukum dan Negara, cet. I. Bandung: Nusa Media.

Konstitusi, M. (2014). Ikhtisar Putusan Perkara Nomor 100/PUU-XI/2013 tentang Kedudukan Pancasila Sebagai Pilar Berbangsa dan Bernegara. Jakarta: Mahkamah Konstitusi.

Matthew Soberg Shugart, J. M. (2012). Electoral Dynamics: Efficiency and Inefficiency, Presidents and Assemblies Constitutional Design and Electoral Dynamics. Cambridge : Cambridge University Press.

Mietzner, M. (2010). Political Conflict Resolution and Democratic Consolidation in Indonesia: The Role of the Constitutional Court. Journal of East Asian Studies, i-ii.

Soerjono Soekanto, S. M. (2007). Penelitian Hukum Normatif; Suatu Tinjauan Singkat, ed.1. Jakarta: RajaGrafindo Persada.

Vermonte. (2006). People, Places and Voting. Wigins, A. H. (2015). The 2014 Indonesian Legislative and Presidential Elections: Embracing Democracy, Social Alternatives. Proquest, 42-50. 